\title{
Contribution of Androgens to the Gender Difference in Leptin Production in Obese Children and Adolescents
}

\author{
Martin Wabitsch, ${ }^{\star \ddagger}$ Werner F. Blum, ${ }^{\S \|}$ Rainer Muche, ${ }^{* \ddagger}$ Mike Braun, ${ }^{\star \ddagger}$ Frank Hube, ${ }^{\rrbracket}$ Wolfgang Rascher, ${ }^{\| b e r h a r d ~ H e i n z e, ~}{ }^{\star \ddagger}$ \\ Walter Teller, ${ }^{\star \ddagger}$ and Hans Hauner" \\ *Department of Pediatrics I, and ${ }^{\ddagger}$ Department of Biometry and Medical Documentation, University of Ulm, D-89075 Ulm, Germany; \\ ${ }^{\S}$ Department of Pediatrics, University of Gießen, D-35392 Gießen, Germany, "Lilly Deutschland, D-61350 Bad Homburg, Germany; \\ and "Diabetes Research Institute, D-40225 Düsseldorf, Germany
}

\begin{abstract}
Recent studies demonstrated significantly higher serum leptin concentrations in females as compared with males, even after correction for differences in body fat mass. The aim of our study was to measure serum leptin concentrations in a large group of obese children and adolescents to determine the possible role of sex steroid hormones on both leptin serum concentrations and production in human adipocytes. Obese girls were found to have significantly higher leptin concentrations than boys at the same degree of adiposity (25.2 \pm 14.1 vs. $17.2 \pm 12.6 \mathrm{ng} / \mathrm{ml}, P<0.001)$. In a multiple regression analysis with age and body mass index (percent body fat) as fixed variables, it turned out that testosterone had a potent negative effect on serum leptin in boys, but not in girls. In vitro experiments using newly developed human adipocytes in primary culture showed that both testosterone and its biologically active metabolite dihydrotestosterone are able to reduce leptin secretion into the culture medium by up to $62 \%$. Using a semiquantitative reverse transcriptase-PCR method, testosterone was found to suppress leptin mRNA to a similar extent. These results suggest that, apart from differences in body fat mass, the higher androgen concentrations in obese boys are responsible for the lower leptin serum concentrations compared with obese girls. (J. Clin. Invest. 1997. 100:808-813.) Key words: androgens $\bullet$ gender difference $\bullet$ human adipose tissue $\bullet$ leptin
\end{abstract}

\section{Introduction}

Leptin is an adipocyte-specific protein that is secreted into the circulation and may represent an important afferent signal involved in the regulation of body weight $(1,2)$. The lack of leptin in mice results in obesity as described for the ob/ob mouse model (1), and administration of leptin to these animals and other rodent models of obesity decreases body weight by reducing food intake and increasing energy expenditure (3-5). There is now evidence from many studies that leptin production corresponds to the size of the body fat stores, but its ex-

Address correspondence to Martin Wabitsch, M.D., Department of Pediatrics, University of Ulm, Prittwitzstrasse 43, D-89075 Ulm, Germany. Phone: 49-731-502-7790; FAX: 49-731-502-7789; E-mail: martin. wabitsch@medizin.uni-ulm.de

Received for publication 15 January 1997 and accepted in revised form 15 May 1997.

J. Clin. Invest.

(C) The American Society for Clinical Investigation, Inc. 0021-9738/97/08/0808/06 \$2.00

Volume 100, Number 4, August 1997, 808-813

http://www.jci.org pression is also acutely regulated by hormonal and possibly nutritional factors (2).

Several studies reported an increased expression of leptin in obese humans both at the mRNA and protein level (6-10). A common finding of such studies was that serum leptin levels in humans are closely correlated with the body mass index $(\mathrm{BMI})^{1}$ or other measures of body fat, and less but also significantly with serum insulin (10-12). This association was weaker when the intraabdominal fat mass was considered (11), possibly due to a lower expression of leptin in visceral adipose tissue (13). Similar to results obtained in animal experiments, we recently demonstrated that both insulin and cortisol are potent promoters of leptin production in cultured human adipocytes (14).

It has been repeatedly shown that leptin levels are higher in females as compared with males even after correction for the degree of body fat mass (9-11, 15-18). In two studies, obese children also exhibit elevated leptin levels and girls had higher concentrations than boys independent of the degree of obesity $(11,17)$. It is tempting to speculate from these observations that androgens are involved in the regulation of leptin production.

It was the aim of this study to investigate the influence of age, gender, and Tanner stage on leptin levels in a large cohort of obese children. To gain a better understanding of the now well established gender difference, it was our particular interest to study the possible role of androgens on leptin production. For this purpose, additional experiments were performed to examine the effect of androgens on leptin production in cultured human adipocytes.

\section{Methods}

Subjects. A total of 480 obese children and adolescents (208 boys, 272 girls) between 5.5 and $19.4 \mathrm{yr}$ old were included in the study. All subjects were consecutively referred to a pediatric clinic to undergo a weight reduction program consisting of a hypocaloric diet and a physical exercise program for $6 \mathrm{wk}$. All anthropometric measurements, physical examinations, and blood sampling were performed immediately after admission, before starting the weight reduction program. The study protocol was approved by the Ethical Committee of the University of Ulm. Informed consent was obtained from the parents of each participant or when appropriate from the patient.

The physical examination included the assessment of the pubic hair stage (PH) according to Marshall and Tanner $(19,20)$ as an index of the developmental stage. Height was determined to the nearest 0.5 $\mathrm{cm}$, and weight to the nearest $0.1 \mathrm{~kg}$ using a calibrated scale. BMI was calculated as a measure of the degree of obesity (kilograms per square meter). All children had a BMI $>85 \%$ percentile specific for

1. Abbreviations used in this paper: BMI, body mass index; DHEAS, dihydroepiandrosterone sulfate; DHT, dihydrotestosterone; $\mathrm{PH}, \mathrm{pu}$ bic hair stage. 
Table I. Clinical and Laboratory Characteristics of 208 Obese Boys and 272 Obese Girls

\begin{tabular}{lcc}
\hline & \multicolumn{1}{c}{ Boys } & Girls \\
\hline Age $(\mathrm{yr})$ & $12.9 \pm 2.7(5.5-19.4)$ & $13.2 \pm 2.5(5.6-18.9)$ \\
Height $(\mathrm{cm})$ & $161 \pm 15(121-196)$ & $159 \pm 12(116.5-181)$ \\
Weight $(\mathrm{kg})$ & $77.8 \pm 22.5(34.5-158.6)$ & $74.9 \pm 19.8(31.7-139.8)$ \\
BMI $\left(\mathrm{kg} / \mathrm{m}^{2}\right)$ & $29.1 \pm 4.6(18.2-47.1)$ & $29.0 \pm 5.2(17.7-47.0)$ \\
Body fat $(\mathrm{kg})$ & $33.4 \pm 10.9(13.2-85.8)$ & $30.9 \pm 10.5(12.0-57.1)$ \\
Leptin $(\mathrm{ng} / \mathrm{ml})$ & $17.2 \pm 12.6(0.5-69.9)$ & $25.2 \pm 14.1(1.5-76.7)$ \\
Insulin $(\mu \mathrm{U} / \mathrm{ml}) *$ & $18.6 \pm 12.1(4.0-77.0)$ & $17.9 \pm 8.0(4.0-60.0)$ \\
Cortisol $(\mu \mathrm{g} / \mathrm{dl}) *$ & $15.5 \pm 6.5(3.8-34.0)$ & $18.7 \pm 7.6(4.0-46.9)$ \\
Testosterone $(\mathrm{ng} / \mathrm{ml}) *$ & $2.15 \pm 2.05(0.05-6.5)$ & $0.5 \pm 0.5(0.05-5.1)$ \\
DHEAS $(\mu \mathrm{g} / \mathrm{ml})^{*}$ & $2.6 \pm 1.6(0.05-8.6)$ & $2.8 \pm 1.8(0.16-10.0)$ \\
Estradiol $(\mathrm{pg} / \mathrm{ml})^{*}$ & $4.0 \pm 11.5(3.0-55.0)$ & $45.1 \pm 47.8(3.0-369.0)$ \\
& &
\end{tabular}

*Hormone concentrations were measured in only 138 males and 81 females. Data are presented as mean \pm SD and range of values (in parentheses).

age and gender. Percentage body fat was determined in 115 subjects ( 69 boys and 45 girls) by bioimpedance analysis using an equation developed with deuterium dilution as reference method (21). The main clinical characteristics of the children are summarized in Table I.

Laboratory measurements. Blood samples were collected between 0700 and 0800 hours after an overnight fast of $12 \mathrm{~h}$ on the day after admission in 219 subjects ( 138 boys and 81 girls). After centrifugation, serum samples were immediately stored at $-20^{\circ} \mathrm{C}$ until later analysis. Commercially available test kits were used to measure serum insulin (International CIS, Gif-sur-Yvette, France), cortisol, testosterone, estradiol, and dihydroepiandrosterone sulfate (DHEAS) (Immuno Biological Laboratories, Hamburg, Germany). Serum leptin concentrations were measured in all 480 subjects with a specific radioimmunoassay as recently described in detail (14).

Adipose tissue samples. Subcutaneous adipose tissue samples (50$200 \mathrm{~g}$ wet $\mathrm{wt}$ ) were obtained from seven young females (age $30 \pm 5 \mathrm{yr}$, means \pm SD; BMI $29.5 \pm 3.0 \mathrm{~kg} / \mathrm{m}^{2}$ ) undergoing mammary reduction. For comparison, subcutaneous adipose tissue was also obtained from a male subject undergoing abdominal reduction plastic (age $45 \mathrm{yr}$, BMI $39.6 \mathrm{~kg} / \mathrm{m}^{2}$ ). All subjects were otherwise healthy according to physical examination and laboratory tests. Tissue samples were immediately transferred to the laboratory in phosphate-buffered saline containing $20 \mathrm{mg} / \mathrm{ml}$ bovine serum albumin.

Cell culture. The isolation and culture of the adipose tissuederived stromal cells was performed as described previously with minor modifications (22). Briefly, adipose tissue samples were minced into small pieces and digested using $1 \mathrm{mg} / \mathrm{ml}$ collagenase in phosphate buffered saline containing $20 \mathrm{mg} / \mathrm{ml}$ bovine serum albumin, $\mathrm{pH} 7.4$, for 40-50 min under intermittent shaking. After washing and centrifugation steps, including a short incubation with an erythrocyte lysing buffer, stromal cells were cultured in serum-free DME/Ham's F-12 medium (1:1 vol/vol) supplemented with $15 \mathrm{mmol} /$ liter $\mathrm{NaHCO}_{3}, 15$ $\mathrm{mmol} /$ liter Hepes, $33 \mu \mathrm{mol} /$ liter biotin, $17 \mu \mathrm{mol} /$ liter pantothenate, 10 $\mu \mathrm{g} / \mathrm{ml}$ human transferrin, $100 \mathrm{U} / \mathrm{ml}$ penicillin, and $0.1 \mathrm{mg} / \mathrm{ml}$ streptomycin. To induce adipose differentiation, $100 \mathrm{nmol} / \mathrm{liter}$ cortisol and $66 \mathrm{nmol} /$ liter insulin were added (adipogenic medium). The percentage of differentiated fat cells after $16 \mathrm{~d}$ of culture was assessed by microscopically counting the number of lipid-filled cells in relation to total cell number in 10 randomly selected areas per dish, each area representing $1 \mathrm{~mm}^{2}$. In all cultures, the differentiation rate exceeded $50 \%$.

Incubations with testosterone and dihydrotestosterone (DHT), respectively, were performed in the presence of cortisol and insulin to maintain a high basal leptin production (14). Androgens were dissolved in ethanol to a final ethanol concentration of $1 \%$. The fat cell cultures were exposed to androgens for up to $12 \mathrm{~d}$ at the concentrations indicated. Leptin was measured in the culture medium.

Isolation of RNA. RNA was prepared as described previously (14). Lysates were layered on a cesium chloride cushion and centrifuged at 28,000 rpm (Ultracentrifuge, rotor SW40, Sorvall Deutschland, Bad Homburg, Germany) for $29 \mathrm{~h}$ at $20^{\circ} \mathrm{C}$. Pelleted RNA was dissolved with $300 \mu \mathrm{l}$ sodium acetate/Tris buffer and was neutralized by addition of $50 \mu \mathrm{l} 2 \mathrm{M}$ potassium acetate ( $\mathrm{pH}$ 5.5).

$c D N A$ generation and PCR. A detailed description of cDNA synthesis and PCR is given elsewhere (14). Briefly, total RNA was diluted to $0.2 \mu \mathrm{g} / \mu \mathrm{l}$ in Tris/EDTA buffer, and first strand cDNA was prepared using $5 \mu \mathrm{l}$ RNA, Superscript RT reverse transcriptase, and random hexamers (both Gibco BRL, Berlin, Germany) according to the instructions of the manufacturer. cDNA was diluted 1:8 with $\mathrm{H}_{2} \mathrm{O}$ and PCR carried out using $7 \mu$ l diluted cDNA and a PCR primer mix containing 1.0 U Taq polymerase in its $1 \times$ buffer (Gibco BRL), 40 $\mu \mathrm{mol} /$ liter dCTP, dGTP, dTTP, $20 \mu \mathrm{mol} /$ liter dATP, $2.5 \mu \mathrm{Ci}$ of 1,000$3,000 \mathrm{Ci} / \mathrm{mmol}$ (alpha- ${ }^{3} \mathrm{P}$ )-dATP (Amersham International, Braunschweig, Germany), and 10 pmol of each primer in a $50-\mu l$ volume overlaid with $50 \mu \mathrm{l}$ mineral oil. PCR conditions were a denaturation step at $95^{\circ} \mathrm{C}$ for $1 \mathrm{~min}$ followed by 20 cycles of $94^{\circ} \mathrm{C}, 30 \mathrm{~s} ; 55^{\circ} \mathrm{C}, 1 \mathrm{~min}$; $72^{\circ} \mathrm{C}, 1 \mathrm{~min}$. In this semiquantitative reverse transcription-PCR method, two primer sets were used simultaneously in the same tube whereby variation in amount of cDNA and between tubes was taken into account. One primer set was specific for leptin cDNA and the other specific for the transcription factor Sp1, which is ubiquitously expressed and was used as internal standard. To be sure that the amplification of both leptin and Sp1 cDNA was within the exponential range, different numbers of PCR cycles (20-28 cycles) were run. Finally, 22 cycles of PCR amplification were used for the detection of leptin mRNA.

Human leptin gene specific primers; $5^{\prime}$ primer 5'-CTTGGCCCTATCTTTTCTA TGTTC- $3^{\prime}$ and $3^{\prime}$ primer $5^{\prime}$-ATAAGGTCAGGATGGGGTGGAGC-3'. Compared with the published human sequence, the position of the sense primer is bases 34-57 in exon 2 and of the antisense primer is bases 2438-2460 in exon 3. Human Sp1specific primers: $5^{\prime}$ primer $5^{\prime}$-gagagtggctcacagcctgtc- $3^{\prime}$ and $3^{\prime}$ primer $5^{\prime}$-gttcagagcatcag accctg-3' (23). PCR products were analyzed on a $6 \%$ polyacrylamide/7 M urea gel exposed to a Phospho-Imager (Fujix BAS 1000; Fuji Photo Film Co., Tokyo, Japan) screen suitable for quantification. In the absence of transcriptase, the PCR products have not been generated.

Statistical methods. All statistical analysis were done with BMI as an indicator of body fatness in the whole study group $(n=480,208$ boys and 272 girls) or in the subgroup in which hormonal data were obtained ( $n=219,138$ boys and 81 girls) as well as with body fat determined by bioelectrical impedance analysis as another indicator of body fatness in 115 subjects ( 69 boys, 45 girls) in which the hormonal data were also obtained. All variables under investigation were sufficiently normally distributed that parametric analyses could be used. Differences in serum concentrations of leptin between girls and boys were calculated using analysis of covariance, controlling for the influence of age and BMI. Pearson's correlation coefficients between variables under investigation were calculated using linear regression analysis. To investigate the possible influence of the hormones under investigation on leptin concentrations, a multivariate regression analysis with stepwise backward selection of variables was performed where age and BMI were kept as fixed variables in the model. Comparison of leptin production by adipocytes in the absence or presence of androgens was done using Student's $t$ test. All statistical calculations were performed using the Statistical Analysis System software (SAS Version 1990; SAS Institute, Cary, NC).

\section{Results}

Clinical studies. The study population of obese children and adolescents covered a wide range of age as well as of BMI and 


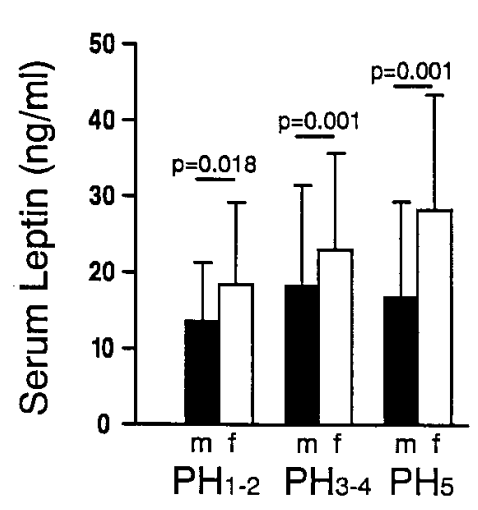

Figure 1. Serum concentrations of leptin at different stages of sexual development in boys ( $\mathbf{\square})$ and girls $(\square)$. The total number of subjects in the groups were, boys: $\mathrm{PH}_{\mathrm{I}-\mathrm{II}}, n=20$; $\mathrm{PH}_{\text {III-IV }}, n=111 ; \mathrm{PH}_{\mathrm{V}}$, $n=77$; girls: $\mathrm{PH}_{\mathrm{I}-\mathrm{II}}, n=15$; $\mathrm{PH}_{\text {III-IV }}, n=130 ; \mathrm{PH}_{\mathrm{V}}$, $n=127$. Serum leptin was measured using a specific radioimmunoassay as described in Methods. (Data are given as means $\pm \mathrm{SD}$.)

body fat estimated by bioelectrical impedance analysis, which was performed in a subgroup (Table I). The correlation coefficients between BMI and body fat measured by bioelectrical impedance analysis were as follows: in boys, $r=0.91, P<$ 0.001 , and in girls, $r=0.92, P<0.001$. Since it has been reported that BMI is closely correlated with more appropriate measures of body fatness early in puberty, while there is significant discordance by Tanner stage V (24), we calculated the correlation coefficients also for: boys (PH I-IV), $r=0.92, P<$ 0.001 ; boys (PH V), $r=0.82, P<0.001$; girls (PH I-IV), $r=$ $0.88, P<0.001$; girls (PH V), $r=0.87, P<0.001$. These data indicate that the relationship between BMI and body fat is less strong in postpubertal boys.

When children were divided into six categories according to pubic hair stage and gender, it was apparent that girls had significantly higher serum leptin concentrations than boys even at preadolescent age. However, the gender difference controlled for BMI in children at PH stages I and II (boys vs. girls: $13.6 \pm 7.7$ vs. $18.4 \pm 10.8 \mathrm{ng} / \mathrm{ml}, P=0.018$ ) was less pronounced than in the children at $\mathrm{PH}$ stage $\mathrm{V}$ (boys vs. girls: $16.8 \pm 12.6$ vs. $28.3 \pm 15.2 \mathrm{ng} / \mathrm{ml}, P<0.001)$. It is also obvious from Fig. 1 that with advancing sexual development as assessed by $\mathrm{PH}$ stage there was a continuous increase in serum leptin levels in the obese girls but not in the obese boys. Comparable significant differences were obtained when leptin lev-

Table II. Linear Regression Analysis between Serum Leptin and Selected Anthropometric and Hormonal Variables in Obese Boys and Girls (Numbers Represent the Pearson's Correlation Coefficients $r$ )

\begin{tabular}{lcc}
\hline & Boys & Girls \\
\hline$n$ & 138 & 81 \\
Age & 0.09 & $0.25^{*}$ \\
BMI & $0.49^{\ddagger}$ & $0.65^{\ddagger}$ \\
Body fat (kg) & $0.51^{\ddagger}$ & $0.65^{\ddagger}$ \\
Fasting insulin & $0.20^{*}$ & $0.45^{\ddagger}$ \\
Cortisol & 0.11 & $0.14^{*}$ \\
Testosterone & $-0.22^{*}$ & 0.01 \\
DHEAS & 0.08 & 0.09 \\
Estradiol & -0.01 & $0.19^{*}$
\end{tabular}

$* P<0.05,{ }^{\ddagger} P<0.001$.

els were controlled for body fat assessed by body impedance analysis (data not shown).

To determine the hormonal factors that may be involved in the regulation of serum leptin concentrations, a linear regression analysis was performed including serum insulin, cortisol, testosterone, DHEAS, and estradiol. As presented in Table II, in addition to BMI and percent body fat, fasting insulin was positively correlated with serum leptin in obese boys, whereas serum testosterone was negatively associated $(r=-0.20, P<$ $0.05)$. In the group of obese girls, there were strong positive associations between serum leptin concentrations and BMI, and percent body fat and fasting insulin, respectively, whereas weak associations were obtained between serum leptin and age, and cortisol and estradiol concentrations, respectively (Table II).

Fig. 2 demonstrates the relationship between serum testosterone and the leptin/BMI ratio, to correct for the degree of adiposity, in both genders. In girls, no significant correlation was found ( $r=-0.07, P=\mathrm{NS})$, whereas in boys an inverse correlation was obvious $(r=-0.35, P<0.01)$ (Fig. 2). An even stronger inverse correlation was found in boys between

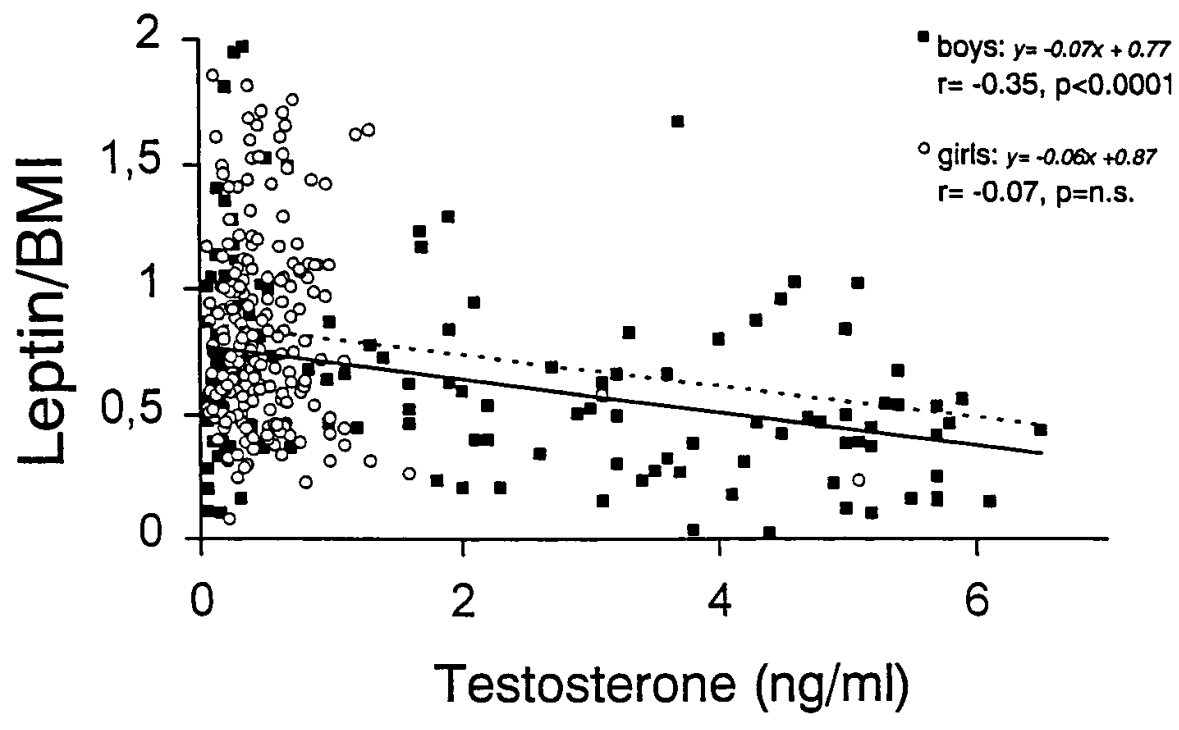

Figure 2. Relationship between the leptin/ BMI ratio and serum testosterone in 138 boys ( $\square)$ and 81 girls ( $\square)$. Regression lines for boys (unbroken line) and girls (dotted line) are shown. 
Table III. Results of a Multiple Regression Analysis with Backward Selection of Variables and Serum Leptin Concentration as Dependent Variable

\begin{tabular}{|c|c|c|c|c|c|c|c|c|c|c|}
\hline & \multicolumn{10}{|c|}{ Regression coefficients } \\
\hline & BMI & Age & PH & Insulin & Cortisol & Testosterone & DHEAS & Estradiol & $\mathrm{R}$ & Intercept \\
\hline \multicolumn{11}{|l|}{ Boys } \\
\hline Step 0 & $1.84 *$ & -0.44 & $7.43^{\ddagger}$ & 0.04 & 0.11 & $-3.68^{*}$ & -0.18 & 0.09 & 0.75 & $-40.8^{*}$ \\
\hline Step 1 & $1.83^{*}$ & -0.45 & $7.38^{\ddagger}$ & 0.04 & 0.10 & $-3.70^{*}$ & & 0.08 & 0.75 & $-40.5^{*}$ \\
\hline Step 2 & $1.87 *$ & -0.41 & $7.43^{\ddagger}$ & & 0.11 & $-3.71 *$ & & 0.07 & 0.75 & $-41.3^{*}$ \\
\hline Step 3 & $1.91 *$ & -0.45 & $7.58^{\ddagger}$ & & 0.13 & $-3.41^{*}$ & & & 0.74 & $-42.3^{*}$ \\
\hline Step 4 & $1.90 *$ & -0.36 & $7.79^{\ddagger}$ & & & $-3.40^{*}$ & & & 0.74 & $-41.6^{*}$ \\
\hline \multicolumn{11}{|l|}{ Girls } \\
\hline Step 0 & $1.92 *$ & -0.76 & 2.73 & $0.34^{\ddagger}$ & $0.22^{\S}$ & 3.59 & $-1.96^{\S}$ & 0.01 & 0.74 & $-32.9 *$ \\
\hline Step 1 & $1.93^{*}$ & -0.68 & 2.70 & $0.33^{\ddagger}$ & $0.22^{\S}$ & 4.47 & $-2.00^{\S}$ & & 0.74 & $-33.7^{*}$ \\
\hline Step 2 & $1.94 *$ & -0.65 & 3.04 & $0.34^{\ddagger}$ & $0.22^{\S}$ & & $-1.62^{\S}$ & & 0.74 & $-34.4^{*}$ \\
\hline Step 3 & $1.93^{*}$ & 0.01 & & $0.33^{\ddagger}$ & $0.25^{\S}$ & & $-1.56^{\S}$ & & 0.74 & $-36.2 *$ \\
\hline
\end{tabular}

BMI and age were fixed variables in the model. R, multiple regression coefficient. ${ }^{*} P<0.001,{ }^{\sharp} P<0.01,{ }^{\S} P<0.05$.

the leptin/body fat ratio and testosterone $(r=-0.46, P<0.01)$ (data not shown). There seems to exist a critical concentration of $\sim 1 \mathrm{ng} / \mathrm{ml}$ testosterone above which this hormone negatively influences serum leptin (Fig. 2).

In the multiple regression analysis with backward selection of variables, and BMI and age (Table III) or body fat and age (Table IV) as fixed variables, it turned out that, after controlling for the effect of other possible influencing variables, testosterone and pubic hair stage were the only variables in the models with a significant effect on serum leptin in boys. In girls, serum leptin was positively affected by fasting insulin (Tables III and IV) and, when BMI was used as an index of body fatness, by cortisol, whereas DHEAS levels were found to be weakly inversely associated with leptin (Table III). When boys and girls were combined and gender was used as a fixed variable, testosterone remained the most powerful hormonal factor that influenced serum leptin concentration. In addition, insulin and cortisol concentrations proved to have a weak positive effect on leptin, whereas DHEAS had a weak negative effect on serum leptin (data not shown).

In another approach, the contribution of testosterone to serum levels of leptin was assessed by examining the effect of the presence and absence of testosterone on the multiple regression coefficient $(\mathrm{R})$ in the multiple regression analysis: $\mathrm{R}$ decreased from 0.75 to 0.60 when BMI was included in the model and from 0.83 to 0.66 when body fat was included in the model, respectively.

In vitro experiments. To unravel how testosterone is able to suppress serum leptin levels, we performed additional in vitro experiments on its effect on leptin production in cultured human adipocytes using an established cell culture system (22). Adipose cells cultured under serum-free conditions in the presence of insulin and cortisol secrete stable amounts of leptin into the culture medium, as described recently (14). When

Table IV. Results of a Multiple Regression Analysis with Backward Selection of Variables and Serum Leptin Concentration as Dependent Variable

\begin{tabular}{|c|c|c|c|c|c|c|c|c|c|c|}
\hline & \multicolumn{10}{|c|}{ Regression coefficients } \\
\hline & Body fat & Age & $\mathrm{PH}$ & Insulin & Cortisol & Testosterone & DHEAS & Estradiol & $\mathrm{R}$ & Intercept \\
\hline \multicolumn{11}{|l|}{ Boys } \\
\hline Step 0 & $0.99 *$ & -0.41 & $9.57^{\ddagger}$ & 0.02 & 0.27 & $-2.87^{*}$ & -0.93 & -0.01 & 0.83 & $-26.3^{\S}$ \\
\hline Step 1 & $0.98 *$ & -0.41 & $9.55^{\ddagger}$ & 0.02 & 0.27 & $-2.91 *$ & -0.97 & & 0.83 & $-26.2^{\ddagger}$ \\
\hline Step 2 & $0.99 *$ & -0.40 & $9.55^{\ddagger}$ & & 0.27 & $-2.94 *$ & -0.93 & & 0.83 & $-26.1^{\ddagger}$ \\
\hline Step 3 & $0.94 *$ & -0.22 & $8.68^{\ddagger}$ & & 0.20 & $-3.22 *$ & & & 0.83 & $-26.0^{\ddagger}$ \\
\hline Step 4 & $0.94 *$ & 0.13 & $9.02^{\ddagger}$ & & & $-3.40 *$ & & & 0.82 & $-28.0^{\ddagger}$ \\
\hline \multicolumn{11}{|l|}{ Girls } \\
\hline Step 0 & $0.96^{\ddagger}$ & -1.42 & 8.34 & 0.28 & 0.08 & 10.81 & -1.24 & -0.06 & 0.73 & -9.61 \\
\hline Step 1 & $0.94^{\ddagger}$ & -1.69 & 9.12 & $0.29^{\S}$ & & 11.51 & -1.11 & -0.06 & 0.73 & -6.49 \\
\hline Step 2 & $0.94^{\ddagger}$ & -1.83 & 9.26 & $0.33^{\S}$ & & 7.74 & & -0.05 & 0.73 & -6.20 \\
\hline Step 3 & $0.99 *$ & -1.78 & 9.39 & $0.34^{\S}$ & & & & -0.04 & 0.72 & -7.21 \\
\hline Step 4 & $0.97 *$ & -1.98 & 9.68 & $0.35^{\S}$ & & & & & 0.72 & -6.04 \\
\hline Step 5 & 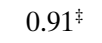 & -0.62 & & $0.37^{\ddagger}$ & & & & & 0.70 & -2.06 \\
\hline
\end{tabular}

Body fat and age were fixed variables in the model. R, multiple regression coefficient. ${ }^{*} P<0.001,{ }^{\ddagger} P<0.01,{ }^{\S} P<0.05$. 

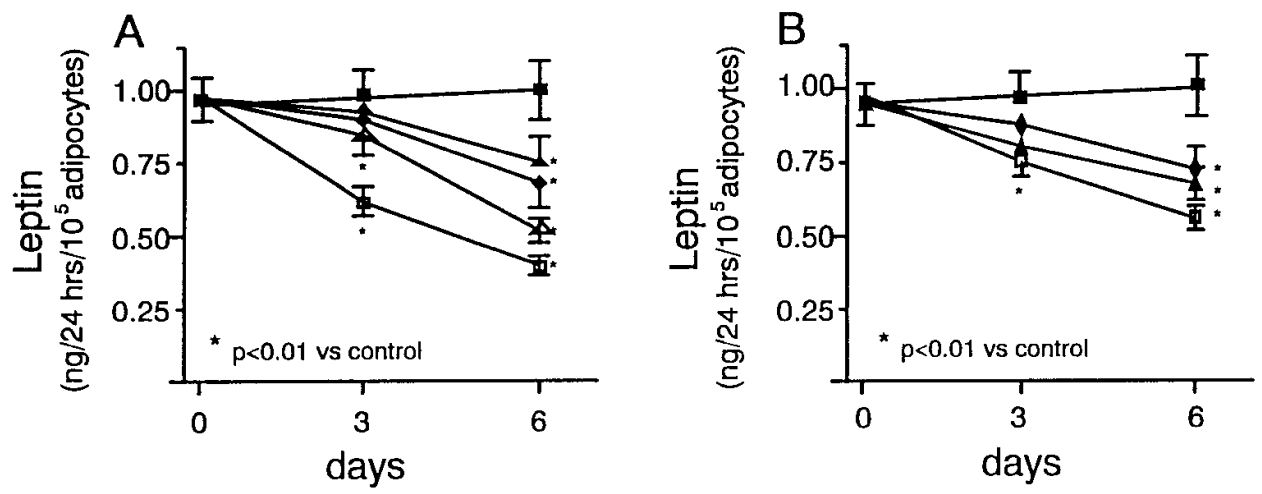

Figure 3. Effect of testosterone and dihydrotestosterone on leptin production in cultured human adipocytes. Fully differentiated human fat cells were exposed to testosterone or dihydrotestosterone at increasing concentrations in a serumfree medium containing insulin and cortisol. The culture medium was changed every third day, including all hormones. Data are given as nanograms $/ 24 \mathrm{~h}$ per $10^{5}$ adipocytes of four experiments in triplicate with cells obtained from four different women. Results obtained with

cultures from one male subject gave comparable results. $(A)$ Control $(\boldsymbol{\square}), 1 \mathrm{ng} / \mathrm{ml}$ testosterone $(\boldsymbol{\Delta}), 10 \mathrm{ng} / \mathrm{ml}$ testosterone $(\bullet), 100 \mathrm{ng} / \mathrm{ml}$ testosterone $(\triangle)$, and 1,000 ng/ml testosterone $(\square) ;(B)$ control $(\mathbf{\square}), 1(\bullet), 10(\mathbf{\Lambda})$, and $100(\square) \mathrm{pg} / \mathrm{ml}$ DHT.

such newly developed human adipocytes were exposed to testosterone or dihydrotestosterone, there was a time- and dosedependent decrease in the amount of leptin detectable in the medium. Compared with control cultures, leptin concentration in the culture medium was reduced by $26 \%$ at $1 \mathrm{ng} / \mathrm{ml}$ testosterone $(P<0.01)$ and by $62 \%$ at $1,000 \mathrm{ng} / \mathrm{ml}$ testosterone $(P<0.01)$ after $6 \mathrm{~d}$ of exposure (Fig. $3 A)$. This suppression remained unchanged thereafter without a further decrease at longer exposure periods (studied for up to $12 \mathrm{~d}$, data not shown). Similar results were obtained when human fat cells were incubated with DHT with a similar dependency on exposure time as seen for testosterone. A significant effect was already detectable at a concentration of $1 \mathrm{pg} / \mathrm{ml}$ DHT for $6 \mathrm{~d}$ (Fig. $3 \mathrm{~B}$ ). A reduction of leptin production was also observed when adipocytes from a male subject were studied (data not shown). Additional experiments using reverse transcriptionPCR were carried out to examine if the suppression by testosterone was due to a change in leptin mRNA levels. Exposure of cultured human fat cells to 10 and $100 \mathrm{ng} / \mathrm{ml}$ testosterone for $6 \mathrm{~d}$ resulted in a significant reduction of the leptin/Sp1 ratio, which was used as an index of leptin expression by $~ 40-60 \%$ (data not shown).

\section{Discussion}

The results of this study indicate a close relationship between serum leptin and BMI or percent body fat in overweight children and adolescents as well as a clear cut gender difference, particularly at $\mathrm{PH}$ stage $\mathrm{V}$, thereby confirming two recent reports in children $(11,17)$. These data are also in agreement with studies on leptin concentrations in lean and obese adults $(9,10,15,16,18)$. However, discrepant findings were reported when leptin levels were corrected for body fat mass. In the first reports, the gender difference was no longer significant when body fat mass was accounted for $(9,10)$, whereas it remained detectable in some more recent studies $(15,16,18)$. In our study, a small but significant gender difference was observed in the children at PH stages I and II in accordance with recently published data (11). At $\mathrm{PH}$ stage $\mathrm{V}$, leptin concentrations in girls were $>50 \%$ higher than those in boys at the same degree of body fat mass.

In a multiple regression analysis, it turned out that serum testosterone has a potent negative effect on leptin concentra- tions, suggesting that the lower leptin concentrations in males are probably due to their higher testosterone levels as compared with females. The observation that the gender difference is already present at PH stages I and II may also be explained by the beginning of increased androgen production at these early stages of sexual development in prepubertal boys (25). In addition to testosterone, $\mathrm{PH}$ stage has been found to be an independent factor influencing serum leptin.

In contrast with boys, serum testosterone was not a predictor of serum leptin concentrations in the obese girls. Obviously, androgen levels in obese girls are not high enough to exert an inhibitory action on leptin, as depicted in Fig. 2. In the multiple regression analysis using BMI as index for body fatness, insulin and, less pronounced, cortisol were found to have significant positive effects on serum leptin, whereas DHEAS had a weak negative influence. These findings are in agreement with experimental data demonstrating that both insulin and cortisol are able to stimulate leptin expression in cultured human adipocytes (14).

The results of our study also show that children and adolescents exhibit a similar increase in leptin levels at increasing body fat mass as adults. Despite the considerable variation in leptin concentration at a given level of obesity, there was a close correlation between leptin and BMI. The association between leptin and percent body fat was even closer, also indicating that obese children have a similar "leptin resistance" as originally postulated for obese adults (10) and that this phenomenon is occurring early in life. However, the definite role of hyperleptinemia in human obesity is far from being understood.

In vitro studies of cultured human adipocytes revealed a suppressive effect of testosterone and its biologically active metabolite dihydrotestosterone on leptin production, suggesting a direct effect of testosterone at the fat cell level. This suppression was found both at the protein and the mRNA level. The existence of androgen receptors in human adipose tissue is well established (26). How testosterone is able to exert this negative effect is currently not clear. Apart from a direct effect of testosterone at the gene level, the possibility cannot be excluded that this suppression is mediated by indirect mechanisms of action such as a stimulation of lipolysis. It is well known that lipolysis is increased in response to testosterone (26), and fatty acids have been reported to decrease leptin ex- 
pression (27). Additional studies are required to elucidate this effect in more detail.

The physiological importance of the inverse relationship between testosterone and leptin concentrations is unknown. There is no evidence that the gender difference in leptin production affects the risk of becoming obese later in life, as obesity is largely equally distributed among males and females. However, if leptin is acting as an important satiety signal in humans, it may be speculated from a biological point of view that the suppression of leptin production by testosterone allows an increased caloric intake that is required to compensate for the increased energy need in males. The higher energy expenditure in males compared with females is due to a greater lean body mass (28), on the one hand, and possibly due to a distinct thermogenic property of androgens (29), on the other. In addition, androgens are also a main determinant of muscle mass $(30,31)$.

In conclusion, our study suggests that androgens have a potent suppressive effect on leptin expression in adipocytes, which may be responsible for the marked gender difference in serum leptin concentrations in addition to the difference in body fat mass. This gender difference becomes evident in early puberty in conjunction with the developing dimorphism in sex steroid hormone production.

\section{Acknowledgments}

The authors gratefully acknowledge the excellent technical assistance of Simone Schmid, the secretarial help of Bettina Wabitsch, and the kind support of Piera Englero. We thank Dr. Mayer and his co-workers, Children's Hospital Murnau, for his support in recruiting patients and collecting serum samples. We are also indebted to Prof. Mühlbauer and his team, City Hospital München-Bogenhausen, for providing adipose tissue samples and Per Bo Jensen, Hagedorn Research Institute Copenhagen, Denmark, for technical advice.

\section{References}

1. Zhang, Y., R. Proenca, M. Maffei, M. Barone, L. Leopold, and J.M. Friedman. 1994. Positional cloning of the mouse obese gene and its human homologue. Nature (Lond.). 372:425-432.

2. Caro, J.F., M.K. Sinha, J.W. Kolaczynski, P.L. Zhang, and R.V. Considine. 1996. Leptin: the tale of an obesity gene. Diabetes. 45:1455-1462.

3. Pelleymounter, M.A., M.J. Cullen, M.B. Baker, R. Hecht, D. Winters, T. Boone, and F. Collins. 1995. Effect of the obese gene product on body weight regulation in ob/ob mice. Science (Wash. DC). 269:540-543.

4. Halaas, J.L., K.S. Gajiwala, M. Maffei, S.L. Cohen, B.T. Chatt, D. Rabinowitz, R.L. Lallone, S.K. Burley, and J.M. Friedman. 1995. Weight-reducing effects of the plasma protein encoded by the obese gene. Science (Wash. DC). 269:543-546.

5. Campfield, L.A., F.J. Smith, Y. Guisez, R. Devos, and P. Burn. 1995. Recombinant mouse OB protein: evidence for a peripheral signal linking adiposity and central neural networks. Science (Wash. DC). 269:546-549.

6. Considine, R.V., E.L. Considine, C.J. Williams, M.R. Nyce, S.A. Magosin, T.L. Bauer, E.L. Rosato, J. Colberg, and J.F. Caro. 1995. Evidence against either a premature stop codon or the absence of obese gene mRNA in human obesity. J. Clin. Invest. 95:2986-2988.

7. Hamilton, B.S., D. Paglia, A.Y.M. Kwan, and M. Deitel. 1995. Increased obese mRNA expression in omental fat cells from massively obese humans. Nat. Med. 1:953-956.

8. Lönnqvist, F., P. Arner, L. Nordfors, and M. Schalling. 1995. Overexpression of the obese $(o b)$ gene in adipose tissue of human obese subjects. Nat.
Med. 1:950-953

9. Maffei, M., J. Halaas, E. Ravussin, R.E. Pratley, G.H. Lee, Y. Zhang, H. Fei, S. Kim, R. Lallone, S. Ranganathan, P.A. Kern, and J.M. Friedman. 1995. Leptin levels in human and rodent: measurement of plasma leptin and ob RNA in obese and weight-reduced subjects. Nat. Med. 1:1155-1161.

10. Considine, R.V., M.K. Sinha, M.L. Heiman, A. Kriauciunas, T.W. Stephens, M.R. Nyce, J.P. Ohannesian, C.C. Marco, L.J. McKee, T.L. Bauer, and J.F. Caro. 1996. Serum immunoreactive-leptin concentrations in normalweight and obese humans. N. Engl. J. Med. 334:292-295.

11. Caprio, S., W.V. Tamborlane, D. Silver, C. Robinson, R. Leibel, S. McCarthy, A. Grozman, A. Belous, D. Maggs, and R.S. Sherwin. 1996. Hyperleptinemia: an early sign of juvenile obesity. Relations to body fat depots and insulin concentrations. Am. J. Physiol. 271:E626-E630.

12. Segal, K.R., M. Landt, and S. Klein. 1996. Relationship between insulin sensitivity and plasma leptin concentration in lean and obese men. Diabetes. 45: 988-991.

13. Hube, F., U. Lietz, M. Igel, P.B. Jensen, H. Tornqvist, H.-G. Joost, and H. Hauner. 1996. Difference in leptin mRNA levels between omental and subcutaneous abdominal adipose tissue from obese humans. Horm. Metab. Res. 28: 690-693.

14. Wabitsch, M., P.B. Jensen, W.F. Blum, C.T. Christoffersen, P. Englaro, E. Heinze, W. Rascher, W. Teller, H. Tornqvist, and H. Hauner. 1996. Insulin and cortisol promote leptin production in cultured human fat cells. Diabetes. 45 : $1435-1438$.

15. Havel, P.J., S. Kasim-Karakas, G.R. Dubuc, W. Mueller, and S.D. Phinney. 1996. Gender differences in plasma leptin concentrations. Nat. Med. 2:949950.

16. Rosenbaum, M., M. Nicolson, J. Hirsch, S.B. Heymsfield, D. Gallagher, F. Chu, and R.L. Leibel. 1996. Effects of gender, body composition, and menopause on plasma concentrations of leptin. J. Clin. Endocrinol. Metab. 81:34243427.

17. Hassink, S.G., D.V. Sheslow, E. de Lancey, I. Opentanova, R.V. Considine, and J.F. Caro. 1996. Serum leptin in children with obesity: relationship to gender and development. Pediatrics. 98:201-203.

18. Ostlund, R.E., J.W. Yang, S. Klein, and R. Gingerich. 1996. Relation between plasma leptin concentration and body fat, gender, diet, age, and metabolic covariates. J. Clin. Endocrinol. Metab. 81:3909-3913.

19. Marshall, W.A., and J.M. Tanner. 1969. Variations in pattern of pubertal changes in girls. Arch. Dis. Child. 44:291-303.

20. Marshall, W.A., and J.M. Tanner. 1970. Variations in pattern of pubertal changes in boys. Arch. Dis. Child. 45:13-23.

21. Wabitsch, M., U. Braun, E. Heinze, R. Muche, H. Mayer, W. Teller, and C. Fusch. 1996. Body composition in 5-18-y-old obese children and adolescents before and after weight reduction as assessed by deuterium dilution and bioelectrical impedance analysis. Am. J. Clin. Nutr. 64:1-6.

22. Hauner, H., G. Entenmann, M. Wabitsch, D. Gaillard, G. Ailhaud, R. Negrel, and E.F. Pfeiffer. 1989. Promoting effects of glucocorticoids on the differentiation of human adipocyte precursor cells cultured in a chemically defined medium. J. Clin. Invest. 84:1663-1670.

23. Kadonaga, J.T., K.R. Carner, F.R. Masiarz, and R. Tijan. 1987. Isolation of cDNA encoding transcription factor Sp1 and functional analysis of the DNA binding domain. Cell. 51:1079-1090.

24. Rico, H., M. Revilla, L.F. Villa, E.R. Hernandez, M. Alvarez-de-Buergo, and M. Villa. 1993. Body composition in children and Tanner's stage: a study with dual-energy x-ray absorptiometry. Metabolism. 42:967-970.

25. Grumbach, M.M. 1975. Onset of puberty. In Puberty, Biologic and Social Components. S.R. Berenberg, H.W. Leiden, and B.V. Krose, editors. H.E. Stenfert Krose, Leiden, Netherlands. pp 1-21.

26. Xu, K., G. DePergola, and P. Björntorp. 1990. The effects of androgens on the regulation of lipolysis in adipose precursor cells. Endocrinology. 126: 1229-1234.

27. Rentsch, J., and M. Chiesi. 1996. Regulation of ob gene mRNA levels in cultured adipocytes. FEBS Lett. 379:55-59.

28. Ravussin, E., S. Lillioja, T.E. Anderson, and C. Bogardus. 1986. Determinants of 24-hour energy expenditure in man. J. Clin. Invest. 79:1568-1578.

29. Clark, C.L., and S.M. Garn. 1954. Relationship between ketosteroid excretion and basal oxygen consumption. J. Appl. Physiol. 6:546-550.

30. Mooradian, A.D., J.E. Morley, and S.G. Korenman. 1987. Biological actions of androgens. Endocr. Rev. 8:1-28.

31. Bhasin, S., T.W. Storer, N. Berman, C. Callegari, B. Clevenger, J. Phillips, T.J. Bunnell, R. Tricker, A. Shirazi, and R. Casaburi. 1996. The effects of supraphysiological doses of testosterone on muscle size and strength in normal men. N. Engl. J. Med. 335:1-7. 